\title{
The Role of Hepatic Iron Stores in the Control of Iron Absorption *
}

\author{
Lewis R. Weintraub, Marcel E. Conrad, and William H. Crosby with the \\ TECHNiCAL ASSISTANCE OF ARTHuR L. Foy \\ (From the Department of Hematology, Walter Reed Army Institute of Research, Walter \\ Reed Army Medical Center, Washington, D. C.)
}

The mechanisms that regulate iron absorption by the gastrointestinal tract are not known. Clinical and experimental work suggests that decreased iron stores (1-3) or increased rate of erythropoiesis $(2,4)$ may be factors causing increased absorption of iron from the gut. The purpose of this paper is to describe the role of the hepatic iron stores as a stimulus to intestinal absorption of iron.

In the rat subjected to partial hepatectomy, the liver returns to its original presurgical weight between the seventh and fourteenth postoperative days (5). This is due to a generalized hyperplasia of the remaining lobes rather than to the regeneration of the removed lobe or to growth of a new appendage. Thus there is a reduction in the total size and concentration of the hepatic iron stores without blood-letting or marrow hyperplasia.

\section{Methods}

Male albino rats (W.R.C.F. ${ }^{1}$ strain) weighing 250 to $300 \mathrm{~g}$ were used in this study. The principles of laboratory animal care as promulgated by the National Society for Medical Research were observed.

With the rat under pentobarbital sodium (Nembutal) anesthesia, a mid-line abdominal incision was made, and the left lateral and median lobes of the liver were excised (5). The average total weight of the removed lobes was $7 \mathrm{~g}$ and was approximately two-thirds of the whole liver. In the sham hepatectomized rats, an abdominal incision and manipulation of the liver were performed. The test dose for iron absorption studies was $0.5 \mu$ c ferrous ${ }^{59}$ citrate per $0.25 \mathrm{mg}$ ferrous sulfate per 0.5 $\mathrm{ml}$ distilled water, administered through an olive-tipped 17-gauge endoesophageal tube to rats fasted for 16 hours. Whole-body radioactivity $(0.8 \mathrm{Mev} \rightarrow \infty)$ was measured in a small-animal wholebody liquid scintillation detector ${ }^{2} 3$ hours and 7 days after dosing to determine

* Submitted for publication June 28, 1963; accepted September 19, 1963.

1 WRCF $=$ Walter Reed Carworth Farm.

2 Packard ARMAC, Packard Instrument Co., La Grange, IIl. the percentage of the test dose absorbed by the rats. The reliability of this technique has been reported previously (6). Statistical analyses of the paired absorption studies were performed by the $t$ test.

Whole rat livers and spleens were homogenized. Hemosiderin and ferritin were separated (7), and the nonheme iron content of these fractions was determined (8). Bloodletting was performed by insertion of a heparinized capillary tube into the retro-orbital venous plexus.

Red blood cell incorporation of $\mathrm{Fe}^{50}$ was measured 18 hours after the iv administration of $1 \mu \mathrm{c}$ ferrous ${ }^{50}$ citrate per 0.06 gamma iron per $0.25 \mathrm{ml}$ saline. The dorsal vein of the penis was used as the site of injection. At the specified time the animal was bled, and the radioactivity in $1 \mathrm{ml}$ of whole blood was determined in a well-type crystal scintillation detector. ${ }^{3}$ The whole blood volume of the rat was presumed to be $5 \%$ of the body weight (9). The following formula was used to quantify radioactive iron incorporated into red blood cells:

Per cent red blood cell uptake

$$
=\frac{0.05 \times \text { body wt } \times \mathrm{cpm} \mathrm{ml} \text { whole blood }}{\text { total } \mathrm{cpm} \text { injected. }}
$$

\section{Results}

Analyses of the liver excised from rats showed each to contain 0.6 to $0.8 \mathrm{mg}$ of nonheme iron. To ascertain whether normal animals measurably increase absorption of iron from the gut after a similar loss of hemoglobin iron, $1.5 \mathrm{ml}$ of blood was withdrawn from rats. This constituted a loss of approximately $0.6 \mathrm{mg}$ of iron. Five days after phlebotomy, these animals absorbed more iron than a comparable nonbled group $(p<0.05)$ (Table I).

Iron absorption studies were performed in partially hepatectomized and sham-hepatectomized rats 7,14 , and 21 days after surgery. There was no difference in the quantity of iron absorbed by either group at weekly intervals after surgery (Table II).

\footnotetext{
3 Packard Auto Gamma Spectrometer, Model 410 A.
} 
Since hepatectomy might interfere with the gastrointestinal response to iron loss, $2.5 \mathrm{ml}$ of blood was withdrawn from a group of rats 7 days after partial hepatectomy. There was a significant $(p<.05)$ increase in iron absorption when measured 5 days after phlebotomy (Table III).

Bone marrow activity of hepatectomized, shamhepatectomized, and sham-hepatectomized-bled $(1.5 \mathrm{ml})$ rats was measured 5 days after surgery by incorporation of $\mathrm{Fe}^{59}$ into red blood cells. Increased incorporation of iron was observed only in rats that had been bled (Table IV), the same group with increased gastrointestinal absorption of iron.

TABLE I

Effect of phlebotomy on iron absorption in rats

\begin{tabular}{ccc}
\hline & \multicolumn{2}{c}{ Percentage Fe ${ }^{59}$ absorbed } \\
\cline { 2 - 3 } & Normal & Bled $1.5 \mathrm{ml}$ \\
\hline & 8.4 & 17.9 \\
10.3 & 10.3 \\
7.4 & 11.2 \\
& 5.1 & 15.1 \\
& 22.5 & 17.6 \\
& 8.8 & 19.0 \\
& 13.7 & 12.2 \\
& 6.8 & 39.2 \\
& & 24.5 \\
Mean & 11.0 & 32.2 \\
SE & 1.8 & 19.9 \\
\end{tabular}

That the total body iron store is not the primary mechanism controlling absorption was determined further in iron-loaded animals subjected to phlebotomy. Rats received an im injection of dextran-iron $(12.5 \mathrm{mg})$. This represented approximately twice the amount of iron contained in their red cell mass. Two weeks were allowed for equilibration with body iron stores. Five $\mathrm{ml}$ of blood was then withdrawn from each rat in a group of animals. Five days after phlebotomy, they were tested and found to absorb more iron from the gut than either normal or unbled, ironloaded animals $(\mathrm{p}<.05)$ (Table V).

Total liver nonheme iron was measured at periodic intervals after partial hepatectomy in one group of rats and the bloodletting of $5 \mathrm{ml}$ in another. Livers obtained from normal rats were compared with the treated animals (Figure 1). The hepatic iron stores in control rats increased
TABLE II

Posthepatectomy iron absorption in rats

\begin{tabular}{|c|c|c|c|c|c|c|}
\hline \multicolumn{7}{|c|}{ Percentage $\mathrm{Fe}^{59}$ absorbed } \\
\hline & $\begin{array}{l}\text { Hepa- } \\
\text { tectomy }\end{array}$ & Sham & $\begin{array}{c}\text { Hepa- } \\
\text { tectomy }\end{array}$ & Sham & $\begin{array}{l}\text { Hepa- } \\
\text { tectomy }\end{array}$ & Sham \\
\hline & \multicolumn{2}{|c|}{7 days } & \multicolumn{2}{|c|}{14 days } & \multicolumn{2}{|c|}{21 days } \\
\hline & 14.5 & 27.3 & 12.9 & 9.3 & 12.4 & 10.8 \\
\hline & 8.1 & 10.4 & 20.5 & 15.1 & 6.1 & 11.1 \\
\hline & 10.9 & 4.7 & 14.4 & 11.1 & 16.5 & 13.6 \\
\hline & 12.2 & 2.5 & 12.6 & 5.8 & 5.3 & 3.4 \\
\hline & 6.5 & 9.4 & 9.4 & 16.9 & 7.1 & 6.3 \\
\hline & 13.5 & 8.9 & 10.7 & 8.5 & 10.1 & 19.3 \\
\hline & 6.1 & 4.5 & 16.5 & 7.5 & 9.9 & 4.8 \\
\hline & 7.3 & 12.5 & 9.4 & 10.5 & 4.2 & 10.9 \\
\hline & 15.7 & 13.9 & & & 11.9 & 6.0 \\
\hline & 11.9 & 4.5 & & & 9.7 & 9.2 \\
\hline & 21.1 & 9.2 & & & 32.5 & 8.2 \\
\hline & 13.2 & 16.3 & & & 7.5 & 10.3 \\
\hline & 7.1 & 12.8 & & & 6.3 & 4.9 \\
\hline Mean & $\overline{11.4}$ & 10.5 & 13.3 & 10.6 & 10.7 & 9.1 \\
\hline $\mathrm{SE}$ & 1.2 & 1.8 & 1.4 & 1.4 & 1.2 & 1.2 \\
\hline
\end{tabular}

with age $(10,11)$. In hepatectomized rats the lowest concentration of liver iron was observed 1 week after surgery. Liver weights had nearly returned to preoperative values at that time. The concentration of iron in the livers of the hepatectomized animals gradually increased but did not equal that of the control animals during the 28 days of the study. Phlebotomized rats had a less profound decrease in liver iron concentration than partially hepatectomized animals.

To ascertain if the circulating red cell mass was a source of liver iron in the posthepatectomy state, $1 \mathrm{ml}$ of homologous $\mathrm{Fe}^{59}$-labeled red cells

TABLE III

Effect of posthepatectomy phlebotomy on iron absorption

\begin{tabular}{rrr}
\hline \hline & \multicolumn{2}{c}{ Percentage Fe ${ }^{59}$ absorbed } \\
\cline { 2 - 3 } & Normal & $\begin{array}{c}\text { Hepatectom- } \\
\text { ized and } \\
\text { bled 2.5 ml }\end{array}$ \\
\hline & 20.0 & 16.4 \\
8.6 & 13.3 \\
6.6 & 34.6 \\
6.3 & 29.4 \\
8.6 & 27.1 \\
& 7.4 & 39.8 \\
& 6.5 & 39.5 \\
& 9.0 & 33.1 \\
& 18.1 & 47.4 \\
Mean & 25.0 & 41.4 \\
\cline { 2 - 3 } SE & 11.6 & 31.2 \\
& 1.9 & 3.3 \\
\hline
\end{tabular}


TABLE IV

Evaluation of erythropoiesis after partial hepatectomy

\begin{tabular}{|c|c|c|c|c|c|c|c|c|c|}
\hline & \multicolumn{3}{|c|}{ Partial hepatectomy } & \multicolumn{3}{|c|}{ Normal } & \multicolumn{3}{|c|}{ Bled } \\
\hline & $\underset{\text { crit }}{\text { Hemato- }}$ & $\begin{array}{l}\text { Reticu- } \\
\text { locytes }\end{array}$ & $\begin{array}{c}\% \mathrm{Fe}^{59} \\
\text { incorpor- } \\
\text { ated by } \\
\mathrm{RBC} *\end{array}$ & $\underset{\text { crit }}{\text { Hemato- }}$ & $\begin{array}{l}\text { Reticu- } \\
\text { locytes }\end{array}$ & $\begin{array}{l}\% \mathrm{Fe}^{59} \\
\text { incorpor- } \\
\text { ated by } \\
\text { RBC }\end{array}$ & $\underset{\text { crit }}{\text { Hemato- }}$ & $\begin{array}{l}\text { Reticu- } \\
\text { locytes }\end{array}$ & $\begin{array}{c}\% \mathrm{Fe}^{59} \\
\text { incorpor- } \\
\text { ated by } \\
\text { RBC }\end{array}$ \\
\hline & $\begin{array}{l}40.3 \\
41.5 \\
43 \\
39 \\
42 \\
41 \\
41.5 \\
41 \\
42.5\end{array}$ & $\begin{array}{l}1.8 \\
1.6 \\
1.5 \\
1.6 \\
1.0 \\
1.0 \\
1.1 \\
1.6 \\
1.8\end{array}$ & $\begin{array}{l}39.3 \\
50.3 \\
50.1 \\
49.4 \\
44.0 \\
40.2 \\
50.6 \\
49.5 \\
31.7\end{array}$ & $\begin{array}{l}43.5 \\
43 \\
43 \\
43 \\
42 \\
38.5 \\
45 \\
45\end{array}$ & $\begin{array}{l}1.3 \\
1.4 \\
1.1 \\
1.5 \\
1.7 \\
1.9 \\
1.8 \\
1.8\end{array}$ & $\begin{array}{l}40.6 \\
44.4 \\
39.8 \\
41.2 \\
56.3 \\
62.5 \\
53.7 \\
51.8\end{array}$ & $\begin{array}{l}40.5 \\
41 \\
36.5 \\
39 \\
40.5 \\
40.5 \\
40.5\end{array}$ & $\begin{array}{l}2.7 \\
2.9 \\
2.2 \\
2.4 \\
2.3 \\
3.5 \\
2.6\end{array}$ & $\begin{array}{l}69.7 \\
77.9 \\
64.1 \\
72.0 \\
68.1 \\
81.3 \\
72.3\end{array}$ \\
\hline Mean & $\overline{41.3}$ & $\overline{1.4}$ & 45.0 & 42.9 & 1.6 & 48.8 & 39.9 & 2.7 & 72.2 \\
\hline $\mathrm{SE}$ & & & 2.2 & & & 3.0 & & & 2.8 \\
\hline
\end{tabular}

$* \mathrm{RBC}=$ red blood cells.

TABLE V

Effect of phlebotomy on the iron-loaded rat

\begin{tabular}{|c|c|c|c|}
\hline & $\begin{array}{c}\text { Iron } \\
\text { loaded }\end{array}$ & $\begin{array}{l}\text { Iron loaded } \\
\text { and bled } \\
5 \mathrm{ml}\end{array}$ & Normal \\
\hline & $\begin{array}{l}3.5 \\
6.2 \\
4.3 \\
3.2 \\
3.9\end{array}$ & $\begin{array}{l}23.0 \\
19.4 \\
10.6 \\
24.5 \\
10.6 \\
22.6\end{array}$ & $\begin{array}{r}17.2 \\
5.3 \\
15.3 \\
3.1 \\
11.3\end{array}$ \\
\hline $\begin{array}{l}\text { Mean } \\
\text { SE }\end{array}$ & $\begin{array}{l}4.2 \\
0.5\end{array}$ & $\begin{array}{r}18.5 \\
2.6\end{array}$ & $\begin{array}{r}10.4 \\
2.7\end{array}$ \\
\hline
\end{tabular}

was transfused into rats 24 hours after surgery. Two weeks later the livers were viviperfused and then digested in nitric and sulfuric acid. After the solution was brought to a constant volume of 250 $\mathrm{ml}$, radioactivity was counted in the liquid scintillation detector. There was no significant difference between the hepatectomized and the sham-operated animals in the amount of hepatic radioiron (Table VI).

To determine if redistribution of the remaining iron stores was responsible for the increase in liver iron, the spleens of hepatectomized animals

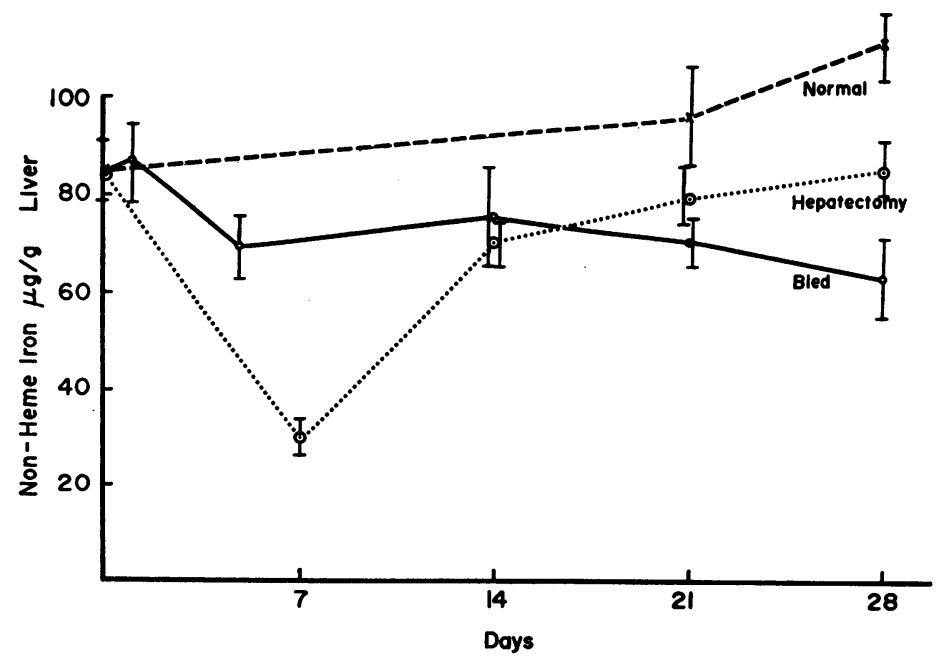

Fig. 1. EFFeCt OF PHLEBOtOMY AND HEPATECTOMY ON NONHEME IRON CONCENTRATION IN LIVER. Each point represents the mean value of five animals. The SE is illustrated by the bar through each point. 
were removed and assayed 2 weeks after the operative procedure. The nonheme iron concentration was significantly lower than that detected in the control group (Table VII). Thus there was a commensurate decrease in the spleen as the liver iron content returned toward normal levels.

\section{Discussion}

Excision of two lobes of the liver produced a 0.6- to $0.8-\mathrm{mg}$ depletion of hepatic iron stores in rats without stimulating a measurable increase in absorption from the gut. This confirms the previous observation of Venkatachalam, Brading, Kaldor, and George (12). In addition, we have shown that removal of the same quantity of iron by bloodletting produces a significant increase in iron absorption. Partial hepatectomy did not eliminate the ability of the gut to respond to a proper signal for increased absorption of iron, since this was observed when hepatectomized animals were bled.

At the time of increased iron absorption after phlebotomy in the normal rat, the liver concentration of iron was approximately three times that of the lowest posthepatectomy level. This suggests that the size and the concentration of the hepatic iron stores were not stimuli to increased iron absorption.

In the regenerating liver the concentration of iron decreased while the organ regained normal size. During the next 3 weeks, liver iron increased but did not reach the concentration of the control animals. As possible mechanisms for the replenishment of liver iron after regeneration, we found no evidence of the following: 1) significantly increased absorption of iron from the

TABLE VI

Liver sequestration of $R B C$ iron

\begin{tabular}{ccc}
\hline \hline & \multicolumn{2}{c}{$\begin{array}{c}\text { Percentage of initial } \\
\text { radioactivity transfused }\end{array}$} \\
\cline { 2 - 3 } & Normal & Hepatectomy \\
\hline & 1.7 & 4.0 \\
& 2.0 & 1.7 \\
& 2.7 & 1.9 \\
& .7 & 1.7 \\
Meanl & 2.7 & 1.2 \\
SE & .7 & 2.1 \\
\hline
\end{tabular}

TABLE VII

Iron concentration in spleen

\begin{tabular}{lcc}
\hline \hline & Normal & $\begin{array}{c}\text { 2 weeks post- } \\
\text { hepatectomy }\end{array}$ \\
\hline$\mu g / g$ & $\mu g / g$ \\
288.5 & 82.9 \\
321.8 & 89.9 \\
& 154.0 & 82.1 \\
& 171.3 & 140.5 \\
& 277.2 & 237.7 \\
Mean & 113.4 & 154.9 \\
SE & 126.1 & 132.4 \\
Range of total & 102.9 & 120.9 \\
\cline { 2 - 2 }$g$ & 194.4 & 130.2 \\
& 33.1 & 19.4 \\
\hline
\end{tabular}

gut, 2) increased deposition of erythrocytic iron in the liver, or 3 ) decreased incorporation of iron into newly formed cells. The transient fall in hematocrit in the week following surgery was due to increased plasma volume and not to diminished red cell mass (13). Hence, the increase in liver iron concentration after the initial depression may have come from the redistribution of remaining tissue storage iron. In support of this hypothesis, we have demonstrated a decrease in the nonheme iron concentration of the spleen as the liver iron concentration returned toward normal. The amount mobilized from this site did not account for the entire increment noted in the liver iron at the same time. The bone marrow and other stores may also have contributed iron to the liver. Possibly, however, increased absorption of iron, undetectable by our methods, may have been partially responsible for the replenishment of liver iron. If hepatectomized animals were followed for several months, their liver iron and total body iron might finally equal that of the normal animals. In any case, one can postulate that direct removal of liver iron is not so effective a stimulus to gastrointestinal absorption of iron as is removal of red blood cells.

Increased absorption of iron occurred in bled, iron-loaded rats but not in animals when the iron store was depleted without stimulus to erythropoiesis. Thus, iron turnover or the rate of erythropoiesis may be the stimulus controlling absorption, rather than the quantity of iron in the body store. 


\section{Summary}

A direct reduction in the content of the liver iron store by partial hepatectomy did not cause a significant increase in iron absorption. An equivalent amount of iron removed by bloodletting did increase absorption. Thus, under the experimental conditions, reduction of the hepatic iron store was not so effective a stimulus to gastrointestinal absorption as was removal of red blood cells.

\section{References}

1. Hahn, P. F., W. F. Bale, J. F. Ross, W. M. Balfour, and G. H. Whipple. Radioactive iron absorption by gastro-intestinal tract. Influence of anemia, anoxia and antecedent feeding. Distribution in growing dogs. J. exp. Med. 1943, 78, 169.

2. Bothwell, T. H., G. Pirzio-Biroli, and C. A. Finch. Iron absorption. I. Factors influencing absorption. J. Lab. clin. Med. 1958, 51, 24.

3. Pirzio-Biroli, G., and C. A. Finch. Iron absorption. III. The influence of iron stores on iron absorption in the normal subject. J. Lab. clin. Med. 1960, $55,216$.

4. Stewart, W. B., P. S. Vassar, and R. S. Stone. Iron absorption in dogs during anemia due to acetylphenylhydrazine. J. clin. Invest. 1953, 32, 1225.
5. Higgins, G. M., and R. M. Anderson. Experimental pathology of the liver: I. restoration of the liver of the white rat following partial surgical removal. Arch. Path. 1931, 12, 186.

6. Forrester, R. H., M. E. Conrad, Jr., and W. H. Crosby. Measurement of total body iron $^{50}$ in animals using whole-body liquid scintillation detectors. Proc. Soc. exp. Biol. (N. Y.) 1962, 111, 115.

7. Yoneyama, M., and K. Kono. Studies on non-hemin iron. J. Biochem. (Tokyo) 1953, 40, 377.

8. Brückmann, G., and S. G. Zondek. An improved method for the determination of non-hemin iron. J. biol. Chem. 1940, 135, 23.

9. Fried, W., L. F. Plzak, L. O. Jacobson, and E. Goldwasser. Studies on erythropoiesis. III. Factors controlling erythropoietin production. Proc. Soc. exp. Biol. (N. Y.) 1957, 94, 237.

10. Kaldor, I., and M. Powell. Studies on intermediary iron metabolism. X. The influence of age and sex on the storage of suplemental dietary iron in the rat. Aust. J. exp. Biol. med. Sci. 1957, 35, 123.

11. Widdowson, E. M., and R. A. McCance. Sexual differences in the storage and metabolism of iron. Biochem. J. 1948, 42, 577.

12. Venkatachalam, P. S., I. Brading, I. Kaldor, and E. P. George. Studies on intermediary iron metabolism. XI. The source of iron in the regenerated liver of the rat after hepatectomy. Aust. J. exp. Biol. med. Sci. 1957, 35, 353.

13. Lowrance, P., and A. Chanutin. The effect of partial hepatectomy on the blood volume in the white rat. Amer. J. Physiol. 1942, 135, 606. 